\title{
Aesculin based glucosamine-6-phosphate synthase inhibitors as novel preservatives for food and pharmaceutical products: in-silico studies, antioxidant, antimicrobial and preservative efficacy evaluation
}

\author{
Amit Lather ${ }^{1}$, Sunil Sharma ${ }^{2}$ and Anurag Khatkar ${ }^{1 *}(\mathbb{D}$
}

\begin{abstract}
Background: Presently available chemical based synthetic preservative have emerged with various side effects, so the aspiration of natural and side effect free novel preservative has been greatly increased. As the natural preservative exhibit poor side effect with improved preservative efficacy. The recent development in computational studies leads advancement in drug designing and discovery of novel glucosamine-6-phosphate synthase (G-6-P synthase) inhibition based natural antimicrobial preservatives. Here, selected aesculin derivatives were screened for G-6-P synthase inhibition via docking study and evaluated for antioxidant, antimicrobial, preservative efficacy as well stability study.
\end{abstract}

Results: Modified aesculin derivatives were designed, synthesized and showed potent G-6-P synthase inhibition with remarkable antimicrobial, antioxidant, preservative efficacy and stability study. The molecular docking with target pdb id 1 moq from G-6-P synthase resulted with better dock score and energy for compound 1 as compared to standard drugs streptomycin, ciprofloxacin, ampicillin and fluconazole, that supported the wet lab results. Among the synthesized compounds, the compound $\mathbf{1}$ possessed good antioxidant activity as compared to standard L-ascorbic acid. The resultant data for antimicrobial activity of aesculin derivatives revealed compound $\mathbf{1}$ as the most potent antimicrobial compound as compared to the standard drugs streptomycin, ciprofloxacin, ampicillin and fluconazole. While compound $\mathbf{2}$ showed better antimicrobial activity as compared to streptomycin, ciprofloxacin, ampicillin. The preservative efficacy test for compound 1 in aloe vera juice and white lotion USP has been showed the log CFU/mL values within the prescribed limit of USP standard and results were comparable to standard sodium benzoate, ethyl paraben and propyl paraben. Compound $\mathbf{1}$ has been found to be within prescribed limit of stability study over six month.

Conclusion: Compound 1 showed the potent G-6-P synthase inhibitory, antioxidant, antimicrobial, preservative efficacy and stability study results as compared to standard drugs taken. The results have found comparable to molecular docking results, and this final compound may be used as new preservatives for food and pharmaceutical products. Moreover, the mechanistic insight into the docking poses was also explored by binding interactions of aesculin

\footnotetext{
*Correspondence: dranuragkhatkarmdurtk@gmail.com;

anuragpharmacy@gmail.com

${ }^{1}$ Laboratory for Preservation Technology, and Enzyme Inhibition Studies,

Faculty of Pharmaceutical Sciences, Maharshi Dayanand University,

Rohtak, Haryana, India

Full list of author information is available at the end of the article
}

(C) The Author(s) 2021. Open Access This article is licensed under a Creative Commons Attribution 4.0 International License, which permits use, sharing, adaptation, distribution and reproduction in any medium or format, as long as you give appropriate credit to the original author(s) and the source, provide a link to the Creative Commons licence, and indicate if changes were made. The images or other third party material in this article are included in the article's Creative Commons licence, unless indicated otherwise in a credit line to the material. If material is not included in the article's Creative Commons licence and your intended use is not permitted by statutory regulation or exceeds the permitted use, you will need to obtain permission directly from the copyright holder. To view a copy of this licence, visit http://creativecommons.org/licenses/by/4.0/. The Creative Commons Public Domain Dedication waiver (http://creativeco mmons.org/publicdomain/zero/1.0/) applies to the data made available in this article, unless otherwise stated in a credit line to the data. 
derivatives inside the pdb id $1 \mathrm{moq}$. These results also supported the results for novel synthesized G-6-P synthase inhibitors.

Keywords: Aesculin, Parabens, G-6-P synthase, Docking, Preservative

\section{Introduction}

Glucosamine-6-Phosphate synthase (G-6-P synthase) catalyzed the first step in hexosamine biosynthesis and converted Fructose-6-Phosphate (Fru-6-P) into GlcN6-P (Glucosamine-6-Phosphate), a precursor of Uridine Diphosphate N-acetyl glucosamine (UDP-NAG). NAG is an essential constituent of the peptidoglycan layer of the microbial cell wall as shown in Fig. 1. Accordingly, G-6-P synthase offers a potential target for the action of antimicrobial agents and hence, it has attracted the interest of several researchers [1].

Moreover, the reported literature revealed for the adverse effects of exiting antimicrobial based preservatives viz. estrogenic effect, contact eczema, endocrine disruption, various types of cancer, etc. Hence, the search of better, and safe preservatives for food, pharmaceutical and cosmetic products seems necessary $[2,3]$.

The plants contains wide variety of phytoconstituents with diverse structural heterogeneity as compared to synthetic compounds and are also considered as an important source of novel and safe therapeutic agents [4]. The 3D-crystallographic structure of enzyme involved in microbial cell wall synthesis i.e. G-6-P synthase is available and can be explored as a novel target for search of better antimicrobial compounds [5]. Moreover, the

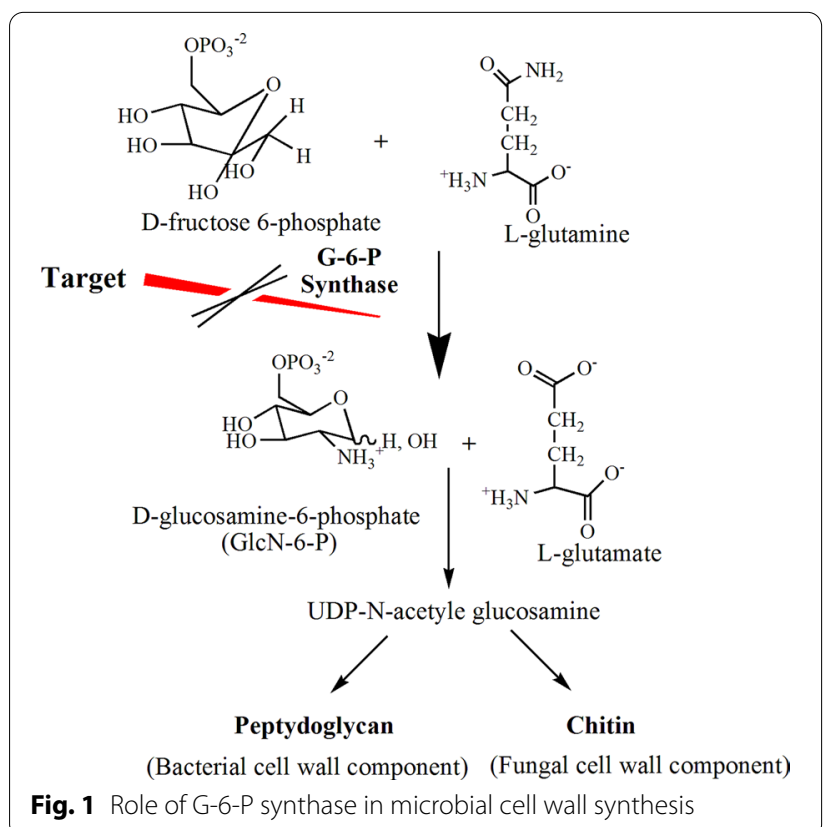

phytoconstituents of plants with reported antimicrobial efficacy may be explored using the molecular docking and large number of molecules can be screened within a short time [6]. Further, the docking simulations if combined with synthetic medicinal chemistry to modify the phytoconstituents, it may help to design highly potent G-6-P synthase inhibitors. Several plant based G-6-P synthase inhibitors such as catechin, luteolin, etc. have been reported for their antimicrobial efficacy [7-9]. Hence, similar to this there is a scope to explore the other selected phytoconstituents for discovery of safe and better G-6-P synthase inhibitors.

Aesculin, $\beta$-D-glucose-6,7-dihydroxy coumarin is a compound derived from the horse chestnut tree has been associated with different biological properties such as anti-oxidant, photo-protective, inhibition of oxidative DNA damage, chemo-preventive, gastro protective, antitumor, etc. [10-12].

It has also been reported in our previous study that aesculin can act as an active inhibitor of G-6-P synthase enzyme based upon the results of molecular docking and ADMET data [13]. Hence, it was planned to explore various derivatives of aesculin for their antimicrobial, antioxidant, preservative efficacy and stability behavior to compare the wet lab results with that of the results of molecular docking.

\section{Experimental}

\section{Materials and methods used}

All the chemicals and reagents used in the experimental part of the study were of analytical grade. Nutrient agar, nutrient broth, sabouraud dextrose agar, and sabouraud broth were purchased from HiMedia Laboratories (Mumbai, India). Aesculin, 2,2-diphenyl-1-picrylhydrazyl (DPPH), anilines, hydrochloric acid were purchased from Sigma Aldrich (Germany), LobaChemie (Mumbai, India), and SRL (Mumbai, India). Reaction progress was checked by thin-layer chromatography (TLC) method. Standard streptomycin, ampicillin, ciprofloxacin, and fluconazole were obtained from Belco Pharma, Bahadurgarh (India). The standard microbial strains E. coli 45 , S. aureus 3160 , P. aeruginosa 1934, C. albicans 183 and $A$. niger 282 were obtained in lyophilized form from MTCC, Chandigarh (India). Melting point was recorded by the Sonar melting point apparatus. FTIR spectra were recorded on Perkin Elmer FTIR spectrophotometer, ${ }^{1} \mathrm{H}$ NMR, and ${ }^{13} \mathrm{C}$ NMR spectra were recorded on Bruker Avance II 400 NMR 
spectrometer. Mass spectra were recorded on Waters Micromass Q-ToF Micro instrument while the elemental analysis was done by Perkin Elmer 2400 elemental analyzer.

\section{Molecular docking}

The three-dimensional structures of aesculin derivatives were constructed by using Chemdraw ultra 8 , and energy was minimized with the LigPrep tool of Schrodinger Maestro. The X-ray crystal structures of G-6-P synthase were downloaded from the Protein Data Bank (http:// www.rcsb.org/pdb). PDB ID 1MOQ (resolution of 1.57 $\AA$ ) was selected on the basis of the lowest resolution as well availability and water molecules (except those coordinated to metals and between the ligand-protein) were removed with the help of Schrodinger protein preparation wizard [14]. The energy-restrained of the protein structure target site optimization of targeted protein G-6-P synthase was done by using Optimized Potential for Liquid Simulations (OPLS-2005) as force field. The partial charges were computed according to the OPLS2005 force field (32 stereoisomers, tautomers, and ionization) on biological $\mathrm{pH}$. All the calculations were carried out by using Schrodinger, Inc. (New York, USA) software Maestro 11 with an induced fit docking (IFD) method. The ligands prepared after energy minimization was used for molecular docking studies. All the computational work was performed in Laboratory for preservation technology and Enzyme Inhibition Studies, Department of Pharmaceutical Sciences, M.D. University, Rohtak, INDIA, was used for all computational work $[15,16]$.

\section{ADMET analysis}

Quick prop from Schrodinger was utilized for in-silico prediction of ADME properties of proposed and synthesized aesculin derivatives. Various ADME parameters were calculated such as Log P, number of rotatable bonds, number of hydrogen acceptor, Log BB, and number of hydrogen bond donor atoms. Lipinski's rule of five was also used for the prediction of a drug-like profile of newly synthesized derivatives.

\section{Procedure for synthesis of aesculin derivatives}

Aesculin derivatives were synthesized by some modifications in the procedure of Yang et al. 2006 as outlined in Fig. 2 [17]. The proposed derivatives were synthesized with substituted aniline $(0.01 \mathrm{~mol})$ taken in a round bottom flask. To this reaction mixture, concentrated hydrochloric acid was added dropwise with continuous stirring. Aesculin $(0.01 \mathrm{~mol})$ was dissolved in ethanol $(50 \mathrm{~mL})$ in equimolar concentration and was refluxed. Synthesis of derivatives was monitored by single spot

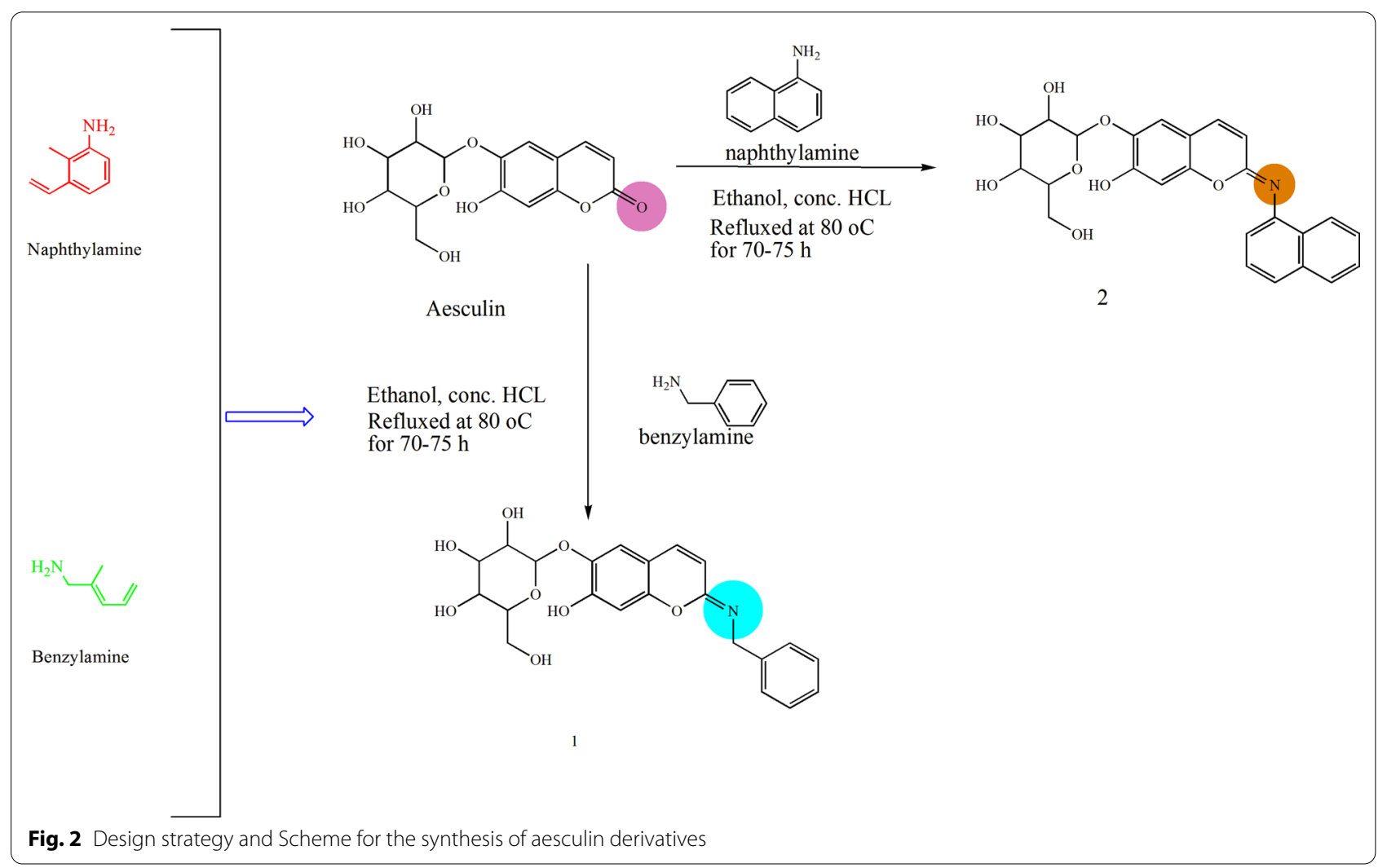


TLC. On the completion of reaction the concentrated reaction mixture was precipitated. Recrystallization of the crude products was done by using alcohol. The final structure of the compounds was confirmed by FTIR, ${ }^{1} \mathrm{H}$ NMR spectra, ${ }^{13} \mathrm{C}$ NMR spectra, mass spectra and elemental analysis.

\section{Spectral data}

2-(3,4-dihydroxyphenyl)-3-(3-nitrophenylamino) chroman-5,7-diol (Compound 1)

$R_{f}$ TLC mobile phase: Methanol: Chloroform (20:80) $=0.56$; Yield $=35 \%$; M.P. $=220-222^{\circ} \mathrm{C}$; M.Wt. $=429.14$; IR $(\mathrm{KBr}$ pellets) $\mathrm{cm}^{-1}: 1383$ (-C-O-C), 1040 (-C-C-), 1684 ( $\left.-\mathrm{C}=\mathrm{N}-\right)$, 2948 (-C-H-), 3387 (-OH-); ${ }^{1} \mathrm{H}$ NMR (400 MHz, CDCL $\left.\mathrm{CL}_{3}\right)$ : $\delta 9.93(\mathrm{~s}, 1 \mathrm{H}), 7.66(\mathrm{~d}, J=9.2 \mathrm{~Hz}, 1 \mathrm{H}), 7.52(\mathrm{~d}, J=8.5 \mathrm{~Hz}$, $1 \mathrm{H}), 7.44(\mathrm{~s}, 1 \mathrm{H}), 7.35$ (d, J=6.0 Hz, 2H), 7.30 (d, J=8.4 Hz, 2H), $7.28(\mathrm{t}, J=8.0 \mathrm{~Hz}, 1 \mathrm{H}), 6.87(\mathrm{~s}, 1 \mathrm{H}), 5.04(\mathrm{~s}, 1 \mathrm{H}), 4.95$ $(\mathrm{d}, J=8.1 \mathrm{~Hz}, 1 \mathrm{H}), 4.62(\mathrm{~d}, J=7.2 \mathrm{~Hz}, 1 \mathrm{H}), 4.59(\mathrm{~d}, J=9.7 \mathrm{~Hz}$, $1 \mathrm{H}), 4.52(\mathrm{~d}, J=10.6 \mathrm{~Hz}, 1 \mathrm{H}), 4.13(\mathrm{~d}, J=8.0 \mathrm{~Hz}, 1 \mathrm{H}), 4.07$ (d, $J=7.8 \mathrm{~Hz}, 1 \mathrm{H}), 3.73(\mathrm{dd}, J=13.8,7.5 \mathrm{~Hz}, 1 \mathrm{H}), 3.50$ (q, $J=9.3$, $8.8 \mathrm{~Hz}, 1 \mathrm{H}), 3.41$ (s, $2 \mathrm{H}), 3.38$ (q, $J=8.5 \mathrm{~Hz}, 1 \mathrm{H}), 3.25-3.23$ $(\mathrm{m}, 1 \mathrm{H}) ;{ }^{13} \mathrm{C}$ NMR $\left(400 \mathrm{MHz}, \mathrm{CDCL}_{3}\right) \delta 160.24,149.30$, 147.84, 145.58, 145.08, 137.34, 129.17, 127.71, 126.97, 114.97, 112.87, 111.52, 102.93, 101.32, 79.51, 74.14, 73.41, 54.69, 38.44, 25.96, 12.61, 10.1; MS ES + (ToF): m/z 429.14 [ $\left.\mathrm{M}^{+}+2\right]$; CHNS: Calc $\left(\mathrm{C}_{23} \mathrm{H}_{23} \mathrm{NO}_{8}\right)$ : C, 61.53; $\mathrm{H}, 5.40 ; \mathrm{N}, 3.26 ; \mathrm{O}$, 29.81; Found C, 61.54; H, 5.42; N, 3.27; O, 29.78.

\section{2-(3,4-dihydroxyphenyl)-3-(naphthalen-1-ylamino) chroman-5,7-diol (Compound 2)}

$R_{f} \quad$ TLC mobile phase: Methanol: Chloroform $(20: 80)=0.60 ; \quad$ Yield $=40 \%$; $\quad$ M.P.; $\quad 168-170 \quad{ }^{\circ} \mathrm{C}$; M.Wt. =465.14;; IR (KBr pellets) $\mathrm{cm}^{-1}: 1166$ (-C-O-C), 1077 (-C-C-), 1457 (-C=C-), 1699 (-C=N-), 2936 (-C-H-), 3390 (-OH-); ${ }^{1} \mathrm{H}$ NMR $\left(400 \mathrm{MHz}, \mathrm{CDCL}_{3}\right) \delta$ $9.93(\mathrm{~s}, 1 \mathrm{H}), 8.32(\mathrm{~d}, J=7.3 \mathrm{~Hz}, 1 \mathrm{H}), 7.95(\mathrm{~d}, J=8.9 \mathrm{~Hz}$, $2 \mathrm{H}), 7.86(\mathrm{~d}, J=8.4 \mathrm{~Hz}, 1 \mathrm{H}), 7.64(\mathrm{~d}, J=8.1 \mathrm{~Hz}, 1 \mathrm{H})$, $7.56(\mathrm{~d}, J=10.8 \mathrm{~Hz}, 2 \mathrm{H}), 7.54(\mathrm{~d}, J=8.1 \mathrm{~Hz}, 1 \mathrm{H}), 7.31$ (s, $1 \mathrm{H}), 7.13(\mathrm{~d}, J=8.6 \mathrm{~Hz}, 1 \mathrm{H}), 6.75(\mathrm{~s}, 1 \mathrm{H}), 5.04(\mathrm{~s}, 1 \mathrm{H})$, $4.95(\mathrm{~d}, J=8.1 \mathrm{~Hz}, 1 \mathrm{H}), 4.62(\mathrm{~d}, J=7.6 \mathrm{~Hz}, 1 \mathrm{H}), 4.13(\mathrm{~d}$, $J=8.1 \mathrm{~Hz}, 1 \mathrm{H}), 4.07(\mathrm{~d}, J=8.6 \mathrm{~Hz}, 1 \mathrm{H}), 3.73(\mathrm{dd}, J=13.8$, $7.5 \mathrm{~Hz}, 1 \mathrm{H}), 3.50$ (q, $J=8.9 \mathrm{~Hz}, 1 \mathrm{H}), 3.41(\mathrm{~s}, 2 \mathrm{H}), 3.38$ (q, $J=8.5 \mathrm{~Hz}, 1 \mathrm{H}), 3.25-3.23(\mathrm{~m}, 1 \mathrm{H}) ;{ }^{13} \mathrm{C}$ NMR $(400 \mathrm{MHz}$, $\left.\mathrm{CDCL}_{3}\right) \delta 163.20,149.30,146.42,146.35,145.76,145.58$, $133.27,129.24,128.14,128.06,126.64,126.56,123.70$, $122.78,122.06,112.87,111.70,110.94,103.36,101.62$, 77.41, 75.43, 73.23, 70.74, 62.21; MS ES+(ToF): $\mathrm{m} / \mathrm{z}$ 467.16 [ $\left.\mathrm{M}^{+}+2\right]$; CHNS: Calc $\left(\mathrm{C}_{25} \mathrm{H}_{23} \mathrm{NO}_{8}\right): \mathrm{C}, 64.51 ; \mathrm{H}$, 4.98; N, 3.01; O, 27.50; Found C, 64.53; H, 4.97; N, 3.02; $\mathrm{O}, 27.47$.
In vitro evaluation of antioxidant potential of synthesized derivatives of selected leads using DPPH method

The ability of the synthesized aesculin derivatives to scavenge DPPH radicals was determined by DPPH free radical scavenging method. The aliquot of test compounds at different concentrations in methanol was mixed. The different concentration used for the evaluation antioxidant potential includes $12.5,25,50,75$ and $100 \mu \mathrm{g} / \mathrm{mL}$. The $0.1 \mathrm{mM}$ solution of $\mathrm{DPPH}$ was prepared in methyl alcohol, and $1 \mathrm{~mL}$ of this solution was further diluted to $3 \mathrm{~mL}$ both for the sample and standard. After $30 \mathrm{~min}$ of incubation in darkness and at ambient temperature, the resultant absorbance was recorded at $517 \mathrm{~nm}$. The tests were performed in triplicate and the \% inhibition of compounds was calculated by using the formula:

$$
\% \text { Inhibition }=\left(\mathrm{A}_{\mathrm{c}}-\mathrm{A}_{\mathrm{s}}\right) \times 100 / \mathrm{A}_{\mathrm{c}}
$$

Here, $A_{c}$ was the absorbance of the control, and $A_{s}$ was the absorbance of the sample [18].

\section{In vitro evaluation of antimicrobial potential of synthesized derivatives of selected leads by using tube dilution method}

The newly synthesized aesculin derivatives were further evaluated for their antimicrobial potential against various MTCC strains viz. E. coli 45, P. aeruginosa 1934, S. aureus 3160, P. mirabilis 3310, A. niger 282 and C. albicans by broth dilution method. The highest dilution of the test compound resulting in no growth of microorganism was recorded as their MIC value. Dilutions of test and standard compounds were prepared in double strength nutrient broth I.P. (bacteria) or Sabouraud dextrose broth I.P. (fungi) [19]. A $0.9 \% \mathrm{NaCl}$ solution was used to adjust the turbidity of bacterial and fungal cultures. The CFU and density of microorganism was adjusted to $0.5 \mathrm{McF}$ arland standards with the help of distilled water [20]. The samples were incubated at $37^{\circ} \mathrm{C}$ for $24 \mathrm{~h}$ (bacteria), at $37^{\circ} \mathrm{C}$ for 7 days (A. niger), and at $37{ }^{\circ} \mathrm{C}$ for $48 \mathrm{~h}$ (C. albicans), and the results were recorded in $\mathrm{PMIC}$.

\section{Evaluation of preservative efficacy of selected antimicrobial/antioxidant derivatives}

White lotion USP and Aloe vera juice was used for evaluation of preservative efficacy of the selected aesculin derivatives. Selected derivatives of aesculin were used as preservatives in equivalent amount in cosmetic and the food product [21]. Aloe vera juice was prepared as per the method described by Ahlawat et al. with slight modifications. The aloe vera juice thus obtained was used for the testing of food preservative efficacy [22, 
23]. White lotion USP was prepared as per the method of Narang et al. The compounds $\mathbf{1}$ and $\mathbf{2}$ in equimolar amount $(0.0013 \mathrm{~mol}$ of methyl paraben) were used as novel preservatives by replacing standard preservatives sodium benzoate, methyl paraben and propyl paraben in both the preparations [24]. Standard strains of P. aeruginosa 1934, S. aureus 3160 , E. coli 45 , A. niger 282, and C. albicans 183 from MTCC were used as common microbial contaminants for evaluation of a preservative efficacy as per the protocol described in I.P., 2010 [25].

\section{Test procedure}

Aloe vera juice and White lotion USP were taken for preservative efficacy study and compound $\mathbf{1}$ was added as test preservative in equimolar quantity $(0.0013 \mathrm{~mol}$ of methyl paraben) to that of standard preservative. A microbial cell count of $1 \times 10^{5}-1 \times 10^{6} \mathrm{cfu} / \mathrm{mL}$ was used for microbial inoculation in a quantity of $0.5-1 \%$ to the volume of the product taken for study. Samples were incubated at room temperature for 28 days. On incubation the CFU/mL of the product was determined at 0 day, 7 days, 14 days, 21 days, and 28 days by using agar pour plate technique [26]. As per the USP standard protocol the $\log$ values of $\mathrm{cfu} / \mathrm{mL}$ was calculated as not less than $2.0 \mathrm{log}$ reduction from initial count at $14^{\text {th }}$ day of incubation and no increase in microbial count from 14th day to 28th days for fungi [27].

\section{Stability study of the selected preservatives as per ICH guidelines}

From the results of preservative efficacy study, compound 1 was selected for further evaluation of its stability behavior as per the $\mathrm{ICH}$ guidelines. The compound 1 was added in the final containers containing the preparations of Aloe vera juice and White Lotion USP. Both the preparations having standard preservative and the test compound 1 were stored at $40^{\circ} \pm 2{ }^{\circ} \mathrm{C}$ at $75 \% \mathrm{RH} \pm 5 \% \mathrm{RH}$ (as per ICH guidelines) and were analyzed for the change in $\mathrm{pH}$ and $\mathrm{cfu} / \mathrm{ml}$ at the time interval of $0,1,2,3,4,5$ and 6 months.

\section{Statistical analysis}

All the data was represented as mean \pm standard deviation (SD) for three triplicates of each sample. One-way ANOVA test at a significance level of $0.05(\mathrm{p}<0.05)$ using MS excel statistical tool was used to analyze the experimental data.

\section{Results and discussion Docking study}

The molecular docking of the proposed aesculin derivatives with the target site of pdb id $1 \mathrm{moq}$ showed that all the inhibitors were exhibiting better binding with different amino acids in active pocket of the enzyme G-6-P synthase. Binding pattern of compound $\mathbf{1}$ and $\mathbf{2}$ with G-6-P synthase has been shown in Fig. 3.

The compound $\mathbf{1}$ and compound $\mathbf{2}$ were selected as the most active compounds based upon the dock score, binding energy, and ADMET parameters. Compound 1 exhibited better dock score $(-10.972)$ and binding energy $(-68.466 \mathrm{~kJ} / \mathrm{mol})$ values as compared to the dock scores $(-5.18,-5.06,-5.12)$ and binding energies $(-37.16 \mathrm{~kJ} / \mathrm{mol},-25.41 \mathrm{~kJ} / \mathrm{mol}$ and $-23.15 \mathrm{~kJ} / \mathrm{mol})$ of standard drugs ciprofloxacin, ampicillin, and fluconazole respectively. Similar results were also reported for compound 2 as well and molecular docking results of different ligands within the binding pocket of enzyme G-6-P synthase environment have been shown in Table 1 [28].

\section{ADMET analysis}

The aesculin derivatives exhibited a suitable drug-like profile and the evaluation of different ADMET parameters have been represented in Table 2. Aesculin derivatives showed the value of various descriptors like rotatable bonds should be $\leq 10$, QPlogBB should be $>1.0$, and QPPCaco cell permeability should be in a range from 4 to 70 [29-31].

\section{Chemistry}

Figure 2 with slight modifications was used for the synthesis of aesculin derivatives. With reference to FTIR data formation of compound $\mathbf{1}$ and $\mathbf{2}$ was confirmed by peak shifted and also confirmed by the ${ }^{13} \mathrm{C}$ spectra. The change in chemical shift value, coupling constant and multiplicities were analyzed by ${ }^{1} \mathrm{HNMR}$ protons signals of synthesized compounds. Mass spectra were also analyzed for the final confirmation of the synthesized compounds. Elemental analysis also confirmed the synthesis of aesculin derivatives where the percentages of $\mathrm{C}, \mathrm{H}$ and $\mathrm{N}$ in synthesized compounds 1-2 was observed within defined limits. The FTIR, ${ }^{1} \mathrm{H}$ NMR, ${ }^{13} \mathrm{C}$ NMR, mass spectroscopy, and elemental analysis data confirmed the chemical structures of synthesized aesculin derivatives (Additional file 1).

\section{Antioxidant potential}

The DPPH free radical scavenging assay confirmed that compound $\mathbf{1}$ possessed good antioxidant activity with inhibitory concentration $\mathrm{IC}_{50} 6.531 \pm 0.042 \mu \mathrm{M}$ as compared to standard L-ascorbic acid $\mathrm{IC}_{50}$ value, $8.110 \pm 0.069 \mu \mathrm{M}$. The results of compounds 2 indicated a moderate antioxidant activity with $\mathrm{IC}_{50} 7.513 \pm 0.076 \mu \mathrm{M}$ while the aesculin itself has antioxidant potential with $\mathrm{IC}_{50} 7.513 \pm 0.076 \mu \mathrm{M}$. 


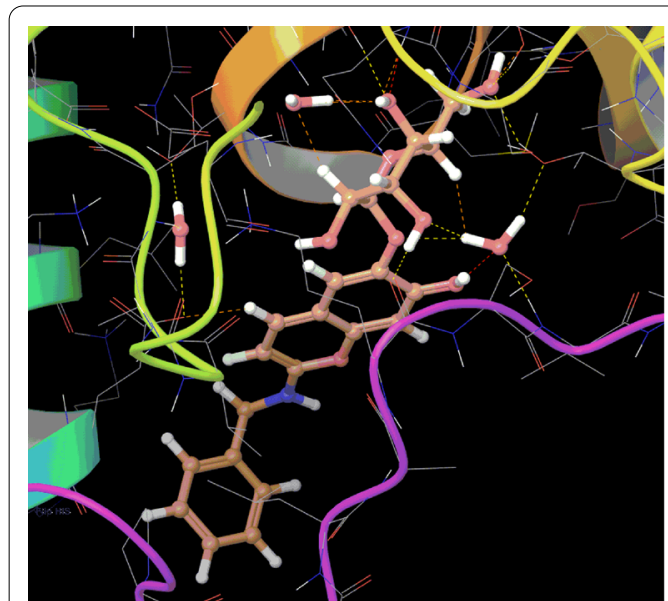

3D Interaction Diagram of Compound 1

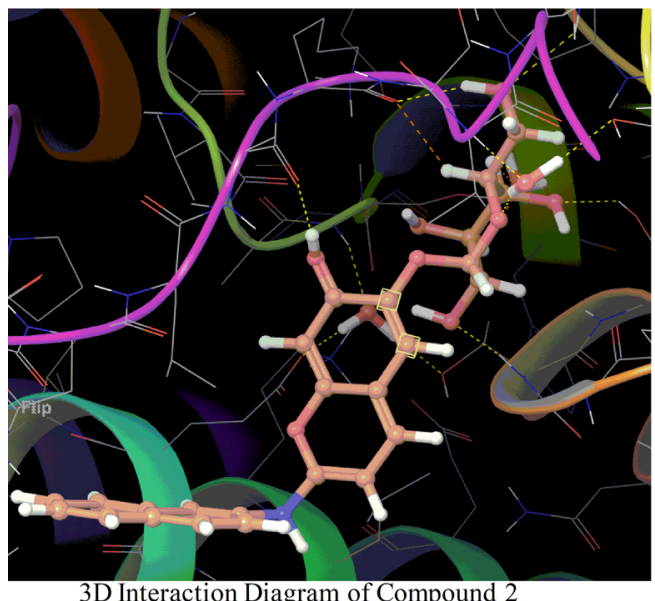

3D Interaction Diagram of Compound 2

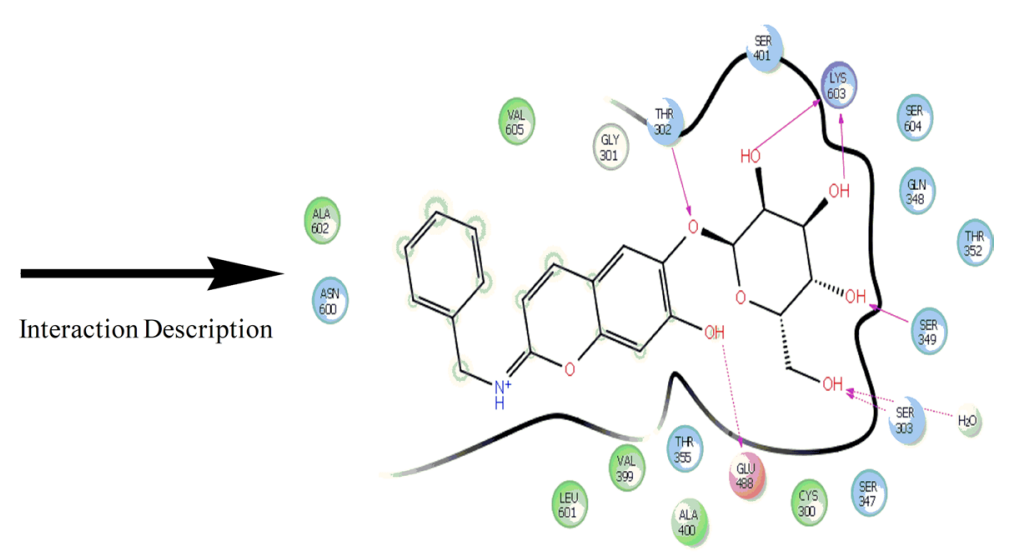

H-bond Ser 303, Ser 349, Glu 488, Lys 603 Hydrophobic interactions Thr 355, Val 605, Cys 300

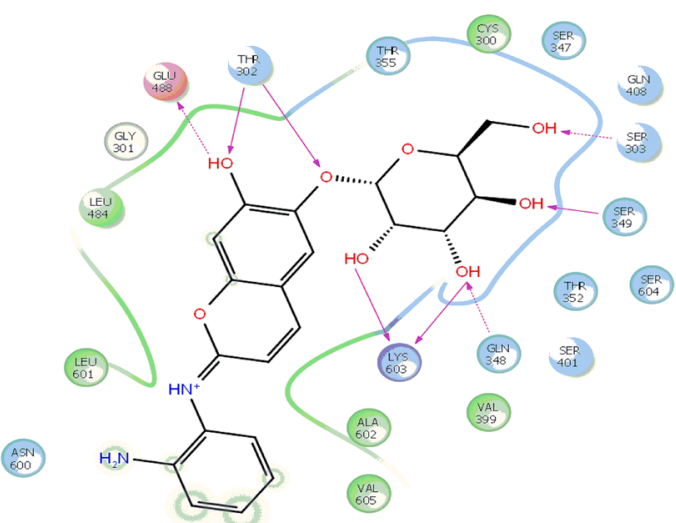

H-bond Lys 603, Gln 348, Ser 349, Ser 303, Thr 302 Hydrophobic interactions Leu 484, Ala 602, Cys 300

Fig. 3 Binding pattern of compound $\mathbf{1}$ and $\mathbf{2}$ with G-6-P synthase

\section{Antimicrobial potential}

The resultant data for antimicrobial activity of above mentioned aesculin derivatives revealed compound $\mathbf{1}$ as the most potent antimicrobial compound (pMIC values $1.53,1.23,1.23$ and $2.13 \mu \mathrm{M} / \mathrm{mL}$ for P. mirabilis, S. aureus and $E$. coli respectively) as compared to the standard drugs streptomycin (pMIC values 1.06, 1.06 and $1.96 \mu \mathrm{M}$ / $\mathrm{mL}$ for $P$. mirabilis, $S$. aureus and $E$. coli respectively), ciprofloxacin (pMIC values 1.12, 1.12 and $1.42 \mu \mathrm{M} / \mathrm{mL}$ for $P$. mirabilis, S. aureus and E. coli respectively), ampicillin (pMIC values 1.14, 0.84 and $1.74 \mu \mathrm{M} / \mathrm{mL}$ for $P$. mirabilis, $S$. aureus and E. coli respectively) and fluconazole (pMIC values 1.83 and $1.53 \mu \mathrm{M} / \mathrm{mL}$ for C. albicans and $A$. niger respectively). While compound 2 showed better antimicrobial activity (pMIC values 1.26, 1.26, 1.57 and $1.57 \mu \mathrm{M} / \mathrm{mL}$ for P. mirabilis, P. aeruginosa, S. aureus and $E$. coli respectively) as compared to streptomycin (pMIC values 1.06 and $1.06 \mu \mathrm{M} / \mathrm{mL}$ for $P$. mirabilis and $S$. aureus respectively), ciprofloxacin (pMIC values 1.42 and $1.42 \mu \mathrm{M} / \mathrm{mL}$ for $P$. mirabilis and $S$. aureus respectively), ampicillin (pMIC values $1.14,0.84$ and $0.84 \mu \mathrm{M} / \mathrm{mL}$ for $P$. mirabilis, $P$. aeruginosa and $S$. aureus respectively). Result of antimicrobial activity of aesculin derivatives (pMIC values) has been presented in Table 3. The result of antimicrobial activity revealed that the synthesized compounds have antimicrobial potential as compared to standards drugs. The probable mechanism of antimicrobial activity of aesculin derivatives may be due to the better inhibition of G-6-P synthase.

\section{Preservative efficacy}

Preservative efficacy study of the Aloe vera juice and White lotion USP were completed in triplicate and the results were reported as mean \pm standard deviation. The result of $\log \mathrm{CFU} / \mathrm{ml}$ for compound 1 revealed that the values were within the prescribed limit as per USP criteria. The selected compound $\mathbf{1}$ reduced the growth of microbes on the 14th day from the initial count and found to be effective on the $28^{\text {th }}$ day, and results were also comparable to sodium benzoate (Figs. 4, 5). Preservative 
Table 1 Docking score, binding energy showed by aesculin derivatives in comparison to standard antimicrobials

\begin{tabular}{|c|c|c|c|}
\hline \multirow[t]{2}{*}{ Compound(s) } & \multirow[t]{2}{*}{ Structure } & \multicolumn{2}{|c|}{ G-6-P synthase binding affinity } \\
\hline & & Docking score & Energy $(\mathrm{kJ} / \mathrm{mol})$ \\
\hline Compound 1 & & -10.972 & -68.466 \\
\hline Compound 2 & & -8.144 & -56.030 \\
\hline Aesculin & & -7.037 & -59.453 \\
\hline \multirow{3}{*}{ Standards } & & & \\
\hline & Ampicillin & $\begin{array}{r}-5.100 \\
-5.065\end{array}$ & -3.103 \\
\hline & Fluconazole & -5.129 & -23.156 \\
\hline
\end{tabular}

Table 2 Different ADMET parameters of aesculin derivatives

\begin{tabular}{|c|c|c|c|c|c|c|c|}
\hline \multirow[t]{2}{*}{ Compound(s) } & \multicolumn{7}{|l|}{ ADMET profile } \\
\hline & $\begin{array}{l}\text { No. of rotatable } \\
\text { bond }\end{array}$ & DonorHB & AcceptHB & QPlogPo/w & QPlogBB & QPPMDCK & QPPCaco \\
\hline Compound 1 & 1 & 5 & 11 & 0.648 & -2.227 & 36.288 & 89.19 \\
\hline Compound 2 & 2 & 6 & 12 & -0.22 & -2.842 & 9.9130 & 26.85 \\
\hline Aesculin & 2 & 4 & 10 & -0.21 & $-3-21$ & 23.33 & 21.21 \\
\hline Streptomycin & 9 & 12 & 15 & -2.06 & -4.20 & 0.78 & 3 \\
\hline Ciprofloxacin & 3 & 2 & 6 & -1.02 & 2.23 & 0.80 & 4 \\
\hline Ampicillin & 4 & 3 & 5 & -1.35 & 0.99 & 0.90 & 0.89 \\
\hline Fluconazole & 5 & 1 & 5 & -2.32 & 0.88 & 0.87 & 0.93 \\
\hline
\end{tabular}

efficacy study results of compound $\mathbf{1}$ in Aloe vera juice and White lotion USP has been presented in Table 4.

\section{Stability study}

The results of six-months continuous stability testing were performed in triplicate and were reported as mean values. The $\mathrm{pH}$ of Aloe vera juice and White lotion USP samples were found to be in the range of 5.5-6.0, which indicated the stability of compound $\mathbf{1}$ as a preservative as compared to that of the standard preservatives sodium benzoate, propyl paraben, and methyl paraben. The results of the antimicrobial study also concluded the no microbial growth in samples containing compound 1 for 6 months period. These results of stability study showed that the products containing acesculin derivatives (compound 1) are stable for 6 months. Results of stability study have been shown in Table 5 . 
Table 3 Result of antimicrobial activity of aesculin derivatives (pMIC values)

\begin{tabular}{|c|c|c|c|c|c|c|}
\hline \multirow[t]{2}{*}{ Compound(s) } & \multicolumn{6}{|c|}{ pMIC values in $\mu \mathrm{M} / \mathrm{mL}$} \\
\hline & P. mirabilis & P. aeruginosa & S. aureus & E. coli & C. albicans & A. niger \\
\hline Compound 1 & 1.53 & 1.23 & 1.23 & 2.13 & 1.83 & 1.53 \\
\hline Compound 2 & 1.26 & 1.26 & 1.26 & 1.57 & 1.57 & 0.96 \\
\hline Aesculin & $<0.83$ & $<0.83$ & $<0.83$ & $<0.83$ & $<0.83$ & $<0.83$ \\
\hline Streptomycin & 1.06 & 1.36 & 1.06 & 1.96 & - & - \\
\hline Ciprofloxacin & 1.12 & 1.42 & 1.12 & 1.42 & - & - \\
\hline Ampicillin & 1.14 & 0.84 & 0.84 & 1.74 & - & - \\
\hline Fluconazole & - & - & - & - & 1.08 & 1.38 \\
\hline
\end{tabular}

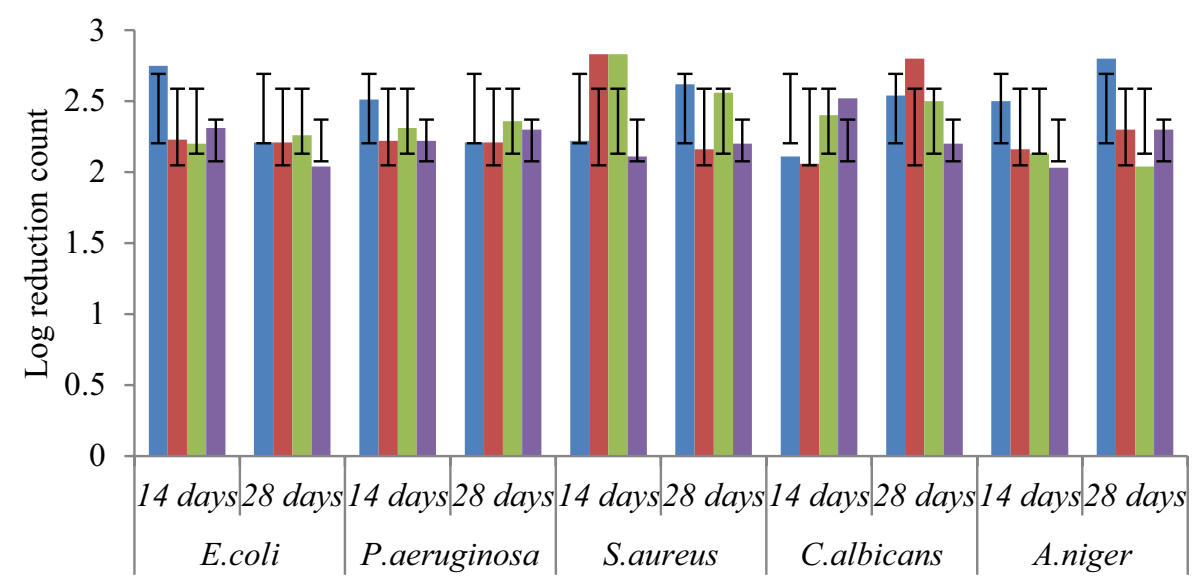

Compound 1

- Sodium Benzoate

- Propyl Paraben

- Ethyl Paraben

Fig. 4 Preservative efficacy results of compound $\mathbf{1}$ in Aloe vera juice and degree of microbial log reduction

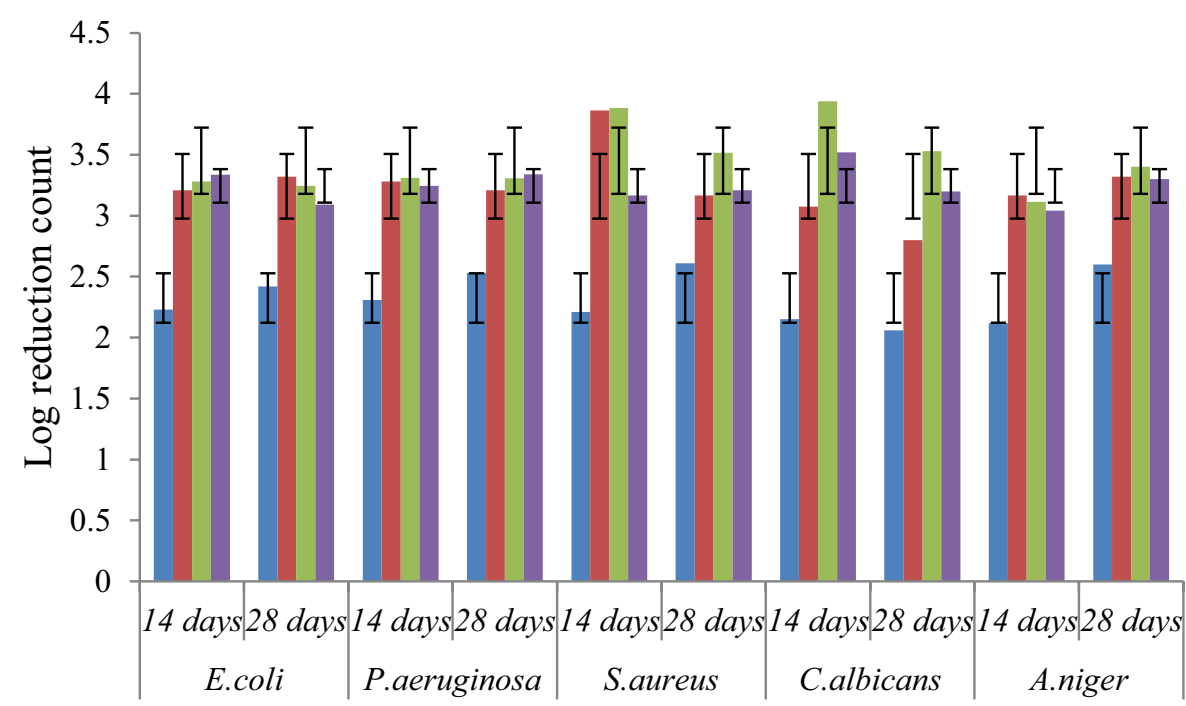

Compound 1

- Sodium Benzoate

- Propyl Paraben

Ethyl Paraben

Fig. 5 Preservative efficacy results of compound $\mathbf{1}$ in White Lotion USP and degree of microbial log reduction 


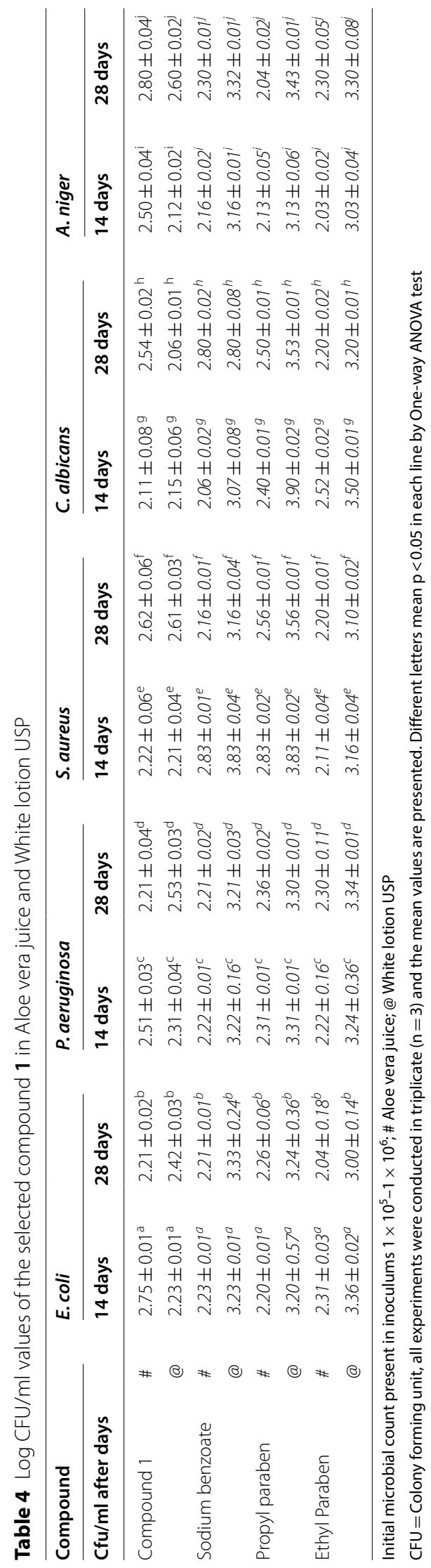


Table 5 Stability studies of compound $\mathbf{1}$ in aloe vera juice and White Lotion USP for $\mathrm{pH}$

\begin{tabular}{|c|c|c|c|c|c|c|c|c|}
\hline \multirow[t]{2}{*}{ Compound(s) } & & \multicolumn{7}{|c|}{ Change in $\mathrm{pH}$ with time } \\
\hline & & 0 month & 1 month & 2 month & 3 month & 4 month & 5 month & 6 month \\
\hline \multirow[t]{2}{*}{ Compound 1} & \# & $5.8 \pm 0.45^{\mathrm{a}}$ & $6.0 \pm 0.50^{b}$ & $5.9 \pm 0.04^{c}$ & $5.7 \pm 0.21^{d}$ & $5.8 \pm 0.34^{e}$ & $5.9 \pm 0.02^{f}$ & $5.8 \pm 0.44^{g}$ \\
\hline & @ & $5.6 \pm 0.23^{\mathrm{a}}$ & $5.9 \pm 0.44^{b}$ & $5.7 \pm 0.44^{c}$ & $5.8 \pm 0.23^{d}$ & $5.7 \pm 0.39^{e}$ & $5.8 \pm 0.29^{f}$ & $6.0 \pm 0.43^{9}$ \\
\hline \multirow[t]{2}{*}{ Sodium benzoate } & $\#$ & $5.6 \pm 0.23$ & $6.9 \pm 0.44$ & $5.7 \pm 0.44$ & $5.8 \pm 0.23$ & $6.7 \pm 0.39$ & $6.8 \pm 0.29$ & $7.0 \pm 0.43$ \\
\hline & @ & $5.7 \pm 0.55$ & $5.6 \pm 0.89$ & $5.6 \pm 0.34$ & $5.6 \pm 0.46$ & $6.0 \pm 0.59$ & $6.0 \pm 0.93$ & $5.6 \pm 0.18$ \\
\hline \multirow[t]{2}{*}{ Propyl paraben } & $\#$ & $5.8 \pm 0.07$ & $5.7 \pm 0.67$ & $5.6 \pm 0.67$ & $5.7 \pm 0.79$ & $5.8 \pm 0.35$ & $5.9 \pm 0.59$ & $5.8 \pm 0.28$ \\
\hline & @ & $5.9 \pm 0.56$ & $5.6 \pm 0.98$ & $6.0 \pm 0.89$ & $5.8 \pm 0.19$ & $5.6 \pm 0.18$ & $5.5 \pm 0.78$ & $5.7 \pm 0.82$ \\
\hline \multirow[t]{2}{*}{ Ethyl paraben } & $\#$ & $5.6 \pm 0.23$ & $6.9 \pm 0.44$ & $5.7 \pm 0.44$ & $5.8 \pm 0.23$ & $6.7 \pm 0.39$ & $6.8 \pm 0.29$ & $7.0 \pm 0.43$ \\
\hline & @ & $5.7 \pm 0.55$ & $5.6 \pm 0.89$ & $5.6 \pm 0.34$ & $5.6 \pm 0.46$ & $6.0 \pm 0.59$ & $6.0 \pm 0.93$ & $5.6 \pm 0.18$ \\
\hline
\end{tabular}

\# Aloe vera juice; @ White lotion USP

All $\mathrm{pH}$ values were recorded in triplicate $(n=3)$ and the mean values are presented. Different letters mean $p<0.05$ in each line by One-way ANOVA test

\section{Conclusion}

From the results of antimicrobial study, preservative and stability study it can be concluded that the aesculin derivatives could act as G-6-P synthase inhibitors as the results also in correlation with molecular docking study. This correlation between different studies alo help in concluding the mechanism for the inhibition of G-6-P synthase with different visual binding interactions. The aesculin compound $\mathbf{1}$ showed superior DPPH scavenging potential, antimicrobial, better preservative efficacy results, and also able to prevent the $\mathrm{pH}$ changes and microbial CFU count in used food and pharmaceutical formulation. Therefore, the synthesized aesculin derivatives $\mathbf{1}$ can be used as novel and superior preservatives for food and pharmaceuticals.

\section{Abbreviations}

ADMET: Absorption, distribution, metabolism, excretion \& toxicity; G-6-P Synthase: Glucosamine-6-phosphate synthase; CYP P450: Cytochromes P450; OATP1B1: Solute carrier organic anion transporter family member 1B1; DHEAS: Dehydroepiandrosterone; PPAR: Peroxisome proliferator-activated receptors; DPPH UDP-N-acetyl: 2,2-Diphenyl-1-picrylhydrazyl; Glucosamine: Uridine diphosphate N-acetylglucosamine; UDP-GICNAc: UDP-N-acetyl glucosamine; Fru-6-P: D-Fructose-6-phosphate; GlcN-6-P: D-Glucosamine-6-phosphate; UDPNAG: Uridine Diphospho-N-acetyl Glucosamine; FTIR: Fourier-transform infrared spectroscopy; IC50: Inhibitory concentration; MIC: Minimum inhibitory concentrations; CFU: Colony forming unit; HBA: Hydrogen bond acceptor; HBD: Hydrogen bond donor; MW: Molecular weight; MTCC: Microbial Type Culture Collection; DMSO: Dimethyl sulfoxide; BOD: Biological oxygen demand; PDB ID: Protein Data Bank Identification; OPLS: Optimized potential for liquid simulations; QS: Quantity sufficient.

\section{Supplementary Information}

The online version contains supplementary material available at https://doi. org/10.1186/s13065-021-00769-8.

Additional file 1. Spectral Data File 1.

\section{Acknowledgements}

The authors are highly thankful to the Head, Department of Pharmaceutical Sciences, M.D. University, Rohtak, INDIA for providing essential facilities to accomplished this research.

\section{Authors' contributions}

The authors AL, SS and AK have designed, synthesized and carried out the work in equal contribution. All authors read and approved the final manuscript.

\section{Funding}

No funding received for this research work from outside sources.

\section{Availability of data and materials}

The datasets used and/or analyzed during the current study are available from the corresponding author on reasonable request.

\section{Declarations}

Ethics approval and consent to participate Not applicable.

\section{Consent for publication}

The Authors hereby consents to publication of the Work in BMC Chemistry Journal.

\section{Competing interests}

The authors declare that they have no competing interests.

\section{Author details}

${ }^{1}$ Laboratory for Preservation Technology, and Enzyme Inhibition Studies, Faculty of Pharmaceutical Sciences, Maharshi Dayanand University, Rohtak, Haryana, India. ${ }^{2}$ Department of Pharmaceutical Sciences, G.J.U.S.\&T., Hisar, India.

Received: 19 August 2020 Accepted: 7 July 2021

Published online: 27 July 2021

\section{References}

1. Bearne SL, Blouin C. Inhibition of Escherichia coli GlcN-6-P synthase by, reactive intermediate analogues, the role of the 2-amino function in catalysis. J Biol Chem. 2002;75(1):135-40.

2. Darbre PD, Harvey PW. Paraben esters: review of recent studies of endocrine toxicity, absorption, esterase and human exposure, and discussion of potential human health risks. J Appl Toxicol. 2008;28(5):561-78. 
3. Tavares RS, Martins FC, Oliveira PJ, Ramalho-Santos J, Peixoto FP. Parabens in male infertility-is there a mitochondrial connection. Reprod Toxicol. 2009;27(1):1-7.

4. Koehn FE, Carter GT. The evolving role of natural products in drug discovery. Nat Rev Drug Dis. 2005;4(3):206-29.

5. Dhiman P, Malik N, Khatkar A. Docking related survey on natural product based new monoamine oxidase inhibitors and their therapeutic potential. CCHTS. 2017;20(6):474-91.

6. Kitchen DB, Decornez H, Furr JR, Bajorath J. Docking and scoring in virtual screening for drug discovery: methods and applications. Nat Rev Drug Dis. 2004;3(11):935-7.

7. Krishna PKV, Harish BGV, Kumar SSR, Kumar GK. Antibacterial activity of leaf extract of Delonix elata and molecular docking studies of luteolin. J Biochem Technol. 2012;3(5):S193-7.

8. Fikrika H, Ambarsari L, Sumaryada T. Molecular docking studies of catechin and its derivatives as anti-bacterial inhibitor for GlcN-6-P synthase. Earth Environ Sci. 2016;31:12009.

9. Deepa M, Devi PR, Alam A. In silico antimicrobial activity of active phyto compounds from the leaf extract of Vitex negundo linn. against glucosamine-6-phasphate synthase. World J Pharma Pharmaceut Sci. 2016;5(1):1144-56.

10. Govori S, Haziri A, Ademi K, Neziraj N. Molecular docking studies of fused coumarin derivatives as inhibitors of GlcN-6. J Environ Sci Health Part A. 2017:2:1-5.

11. Li W, Wang Y, Wang X, Zhang H, He Z, Zhi W, Liu F, Niu X. Gastro protective effect of esculin on ethanol induced gastric lesion in mice. Fundamental Clin Pharmacol. 2017:31(2):174-84

12. Kaneko T, Tahara S, Takabayashi F, Harada N. Suppression of 8-oxo2'deoxyguanosine formation and carcinogenesis induced by $\mathrm{N}$-nitrosobis (2-oxopropyl)amine in hamsters by esculetin and esculin. Free Radic Res. 2004:38:839-46.

13. Lather A, Sharma S, Khatkar A. Virtual screening of novel glucosamine6-phosphate synthase inhibitors. CCHTS. 2018;21(3):1-12.

14. Teplyakov A, Obmolova G, Badet-Denisot MA, Badet B, Polikarpov I. Involvement of the $C$ terminus in intramolecular nitrogen channeling in glucosamine 6-phosphate synthase: evidence from a $1.6 \AA$ crystal structure of the isomerase domain. Structure. 1998;6(8):1047-55.

15. Friesner RA, Banks JL, Murphy RB, Halgren TA, Klicic JJ, Mainz DT, Repasky MP, Knoll EH, Shelley M, Perry JK, Shaw DE. Glide: a new approach for rapid, accurate docking and scoring. Method and assessment of docking accuracy. J Med Chem. 2004;47(7):1739-49.

16. Godschalk F, Genheden S, Soderhjelm P, Ryde U. Comparison of MM/ GBSA calculations based on explicit and implicit solvent simulations. Phy Chem. 2013;15(20):7731-9.
17. Yangn Z, Sun P. Campare of three ways of synthesis of simple Schiff base. Molbank: M514; 2006

18. Blois MS. Antioxidant determinations by the use of a stable free radical. Nature. 1958;181(4617):1199-200

19. Indian Pharmacopoeia Vol-I. Indian Pharmacopoeia Commission. New Delhi: The Controller of Publications; 2007. p. 37.

20. Andrews JM. Determination of minimum inhibitory concentration. J Antimicrobiol Chem. 2001;48(S1):5-16.

21. Maughan RG, Poore RA, Phan BV. Product and procedure for stabilizing Aloe vera gel, US Patent: 0211182A1; 2006

22. Talib MI, Wayal RR, Parate VR. Development of Aloe vera based ready to serve soft drink. Int Conference on Global Trends in Eng Tech Mgt. 2016;87:216-33.

23. Ahlawat KS, Khatkar BS. Processing, food applications and safety of aloe vera products: a review. J Food Sci Technol. 2011;48(5):525-33.

24. Narang R, Narasimhan B, Judge V, Ohlan S, Ohlan R. Evaluaton of preservative effectiveness in an official antacid preparaton. Acta Pharmaceutica Sciencia. 2009;51(3):2259.

25. Indian Pharmacopoeia. Indian Pharmacopoeia Commission, Ghaziabad, India; 2010, p 27-8

26. Khatkar A, Nanda A, Kumar P, Narasimhan B. Synthesis, antimicrobial evaluation and QSAR studies of p-coumaric acid derivatives. Arabian J Chem. 2017;10(2):S3804-15.

27. The United States Pharmacopoeia. Antimicrobial effectiveness testing. Rockville: United States Pharmacopoeial Conventon Inc; 2004.

28. Wojciechowski M, Milewski S, Mazerski J, Borowski E. GlcN-6-P synthase, a novel target for antifungal agents. Molecular modelling studies in drug design. Acta Biochimica Polonica. 2005;52(3):647-53.

29. Hopkins AL, Groom CR. The drug gable genome. Nat Revol Drug Dis. 2002;1:727-33.

30. Veber DF, Johnson SR, Cheng HY, Smith BR, Ward KW, Kopple KD. Molecular properties that influence the oral bioavailability of drug candidates. J Med Chem. 2002:45(12):2615-23.

31. Friesner RA, Murphy RB, Repasky MP, Frye LL, Greenwood JR, Halgren TA, Sanschagrin PC, Mainz DT. Glide: a new approach for rapid, accurate docking and scoring. Method and assessment of docking accuracy. J Med Chem. 2004;47(7):1739-49

\section{Publisher's Note}

Springer Nature remains neutral with regard to jurisdictional claims in published maps and institutional affiliations.

Ready to submit your research? Choose BMC and benefit from:

- fast, convenient online submission

- thorough peer review by experienced researchers in your field

- rapid publication on acceptance

- support for research data, including large and complex data types

- gold Open Access which fosters wider collaboration and increased citations

- maximum visibility for your research: over 100M website views per year

At BMC, research is always in progress.

Learn more biomedcentral.com/submissions 